\title{
Does ECOWAS Macroeconomic Convergence Criteria Satisfy an Optimum Currency Area?
}

\author{
Louis S. Nkwatoh ${ }^{1}$ \\ ${ }^{1}$ Department of Economics, Yobe State University, Nigeria \\ Correspondence: Louis S. Nkwatoh, Yobe State University, Damaturu, 234/620, Nigeria. Tel: 234-8062-218-765. \\ E-mail: sevinkwatoh@gmail.com
}

Received: July 10, 2018; Accepted: August 12, 2018; Published: August 29, 2018

\begin{abstract}
The Economic Community of West African States (ECOWAS) countries have expressed their desire to establish a monetary union by the year 2020 based on six macroeconomic convergence criteria. The desire is predicated on a series of strategies and various treaties ratified and signed by various ECOWAS Heads of governments and Central Banks' Governors with more emphasis on the Maastricht-type set of convergence criteria that must be satisfied by all member countries before they ascend to the envisaged monetary union. Even though the convergence criteria may guarantee macroeconomic stability in a regional grouping, critics assert that the convergence criteria are insufficient and inconsequential to the formation of monetary union. The objective of this study is to ascertain whether ECOWAS countries have met all the macroeconomic convergence criteria making them fit for a monetary union. The analyses indicate that no ECOWAS country has met all the convergence criteria at a given point in time implying that the level of macroeconomic convergence in the region still remains inadequate relative to the set targets. However, WAEMU sub-set economies have met three of the criteria -public debts to GDP Ratio, deficits including grants, annual percentage inflation rate. The simple reason is that WAEMU is an existing monetary union with a common stabilization policy.
\end{abstract}

Keywords: maastricht-type convergence criteria, macroeconomic convergence criteria, monetary union, ECOWAS

\section{Introduction}

Since the creation of the European Monetary Union (EMU), regional groupings around the World contemplating to form a monetary union have adopted a set of macroeconomic convergence criteria (Maastricht-type criteria) that can guarantee the credibility, sustainability and macroeconomic stability of the union. This requires setting up certain appropriate macroeconomic targets (otherwise, known as entry requirements) that must be gradually satisfied by all members prior to the formation of a monetary union. Convergence in macroeconomic stability indicators as a pre-condition for admission into a monetary union safeguards other member countries from negative policy spillover effects (Jekins \& Thomas, 1996). Thus, satisfying the macroeconomic convergence criteria necessitates monetary policy convergence which will ensure an optimal policy for all the union members (Buigut, 2011).

Even though the convergence criteria may guarantee macroeconomic stability in a regional grouping, opponents of this view, however consider the convergence criteria as nominal, hence insufficient and inconsequential to the formation of monetary union. Insufficiency because the key properties enshrined in the Optimum Currency Area theory guarantee real convergence which implicitly influence the nominal convergence criteria. The criteria are inconsequential because monetary unions that existed in $18^{\text {th }}$ and early $19^{\text {th }}$ century: Latin Monetary Union Scandinavian Monetary Union Norway, CEMAC zone among others, did not require any specific convergence criteria. Most importantly, the Maastricht-type convergence criteria were compromised by member countries leading to the current European twin crisis - European debt crisis and unstable Euro zone.

ECOWAS countries have expressed their desire to establish a monetary union by the year 2020 which was predicated initially on four primary convergence and six secondary convergence criteria to be satisfied by all member countries. The four primary convergence criteria, were decisive for the creation of the union, and aimed at keeping certain macroeconomic variables within a particular threshold value. The primary criteria included: a single-digit inflation rate at the end of each year; a fiscal deficit of no more than $4 \%$ of the GDP by the year 2000; 
a central bank deficit-financing of no more than $10 \%$ of the previous year's tax revenues; and a gross external reserves that can give import cover for a minimum of three months (WAMI, 2002).

The six secondary convergence criteria focused on monetary and exchange rate policies management and also on the structure of public accounts (WAMI, 2002). The specified criteria were: prohibition of new domestic default payments and liquidation of existing ones; tax revenue should be equal to or greater than 20 percent of the GDP; wage bill to tax revenue equal to or less than 35 percent; public investment to tax revenue equal to or greater than 20 percent; a stable real exchange rate; and a positive real interest rate (WAMI, 2002).

Seventeen years have gone by since the idea of forming a monetary union was initiated in 2001. Unfortunately, ECOWAS has not been able to achieve its target. The initial launch date for the single currency by WAMZ in 2003 was postponed to 2005 , with the hope that member countries would improve upon their status quo. The launch date was further postponed to 2009 and to 2015 and finally, the Central Bank Governors of ECOWAS have postponed the implementation of the single currency to 2020, due to the inability of member countries to consistently fulfill the initial convergence criteria.

Between 2003 and 2005, ECOWAS suffered two postponements due to: persistence of fiscal dominance, high inflation, and low levels of foreign exchange reserves accumulation; no country met all the criteria; short time frame necessary for the requisite infrastructure to be put in place; national economic policies were at variance with WAMZ objectives; member countries failed to incorporate in their National laws WAMZ Statutes; policy harmonization was weak; payments systems development was still rudimentary; significant variations in statistical standards; sensitisation was still poor and lack of trade integration agenda (Essien, 2009).

By the end of 2009 only Ghana, Gambia and Nigeria had met three of the primary criteria while Sierra Leone met only one criterion. Guinea recorded the worst performance since it did not meet any of the criteria. Specifically, the single digit inflation rate and fiscal deficit, excluding grants criteria were missed (Onuba, 2011). World Bank development indicators (2015) shows that WAZM countries have never maintained a single digit inflation rate which is a pre-condition for a monetary union.

Recently, ECOWAS Heads of States and Governments have compromised the convergence criteria by scaling them down to six (three primary and three secondary criteria) with an ultimate goal of merging both the WAMZ (Gambia, Ghana, Guinea, Nigeria, Liberia and Sierra Leone) and WAEMU (Benin, Burkina Faso, Côte d'Ivoire, Mali, Niger, Senegal and Togo) into a single monetary zone by the start of 2020.

The new primary criteria demands that every member-country's budget deficit should not be more than $3 \%$ of gross domestic product (GDP); the average annual inflation should be single-digit of not more than $5 \%$ by 2019 ; and gross reserves should not be less than three months of imports. The secondary criteria requires that, the public debt to GDP ratio should not be more than $70 \%$; Central Bank financing of budget deficit should not exceed $10 \%$ of previous year's tax revenue; and nominal exchange rate variation should be within $+/-10 \%$ (see, Business News Staff, 2014).

Compromising the convergence criteria gives room for leniency which attracts cost and the likely replication of the Euro-type crisis in the region. For instance, the European sovereign debt crisis cannot be dissociated from the non compliance of the convergence criteria by some Euro members. Prior to the creation of the Euro, core countries compromised the fiscal requirement stipulated in the Maastricht Treaty to accommodate Belgium and Italy that had overwhelming national debts exceeding $60 \%$ of GDP admission requirement which increased their fiscal deficits above the minimum requirement of 3\% deficit of GDP (Harrison, 2010). A peculiar case is that of Greece whose gross debt stood at $152.6 \%$ of its GDP compared to the actual maximum of $60 \%$ admission criteria. Its deficit was $11.47 \%$ of its GDP above the minimum requirement of $3 \%$ deficit of GDP admission requirement (Porca, Stiebinger \& Aiken, 2013). Records show that Greece, Italy, Portugal and Spain falsified their annual reports to prove their good economic performance in order to gain admission into the Euro zone (see Ramos, 2011). Consequently, the compromised convergence criteria have undermined the macroeconomic stability of the entire Euro zone which serves as a lesson to the ECOWAS community.

The unsuccessful attempts to introduce a common currency in the previous targeted dates that have compromised the convergence criteria show that the level of macroeconomic convergence in the region has remained inadequate relative to the set targets. Therefore, the objective of this study is to ascertain whether ECOWAS countries have met the macroeconomic convergence criteria making them fit for a monetary union.

The remaining paper is structured as follows: Section 2 discuses the macroeconomic convergence criteria in perspective. Section 3 presents the demographic indicators of ECOWAS countries, while Section 4 analyses the ECOWAS macroeconomic convergence criteria. The conclusion is contained in Section 5. 


\section{Macroeconomic Convergence Criteria in Perspective}

Economic convergence as discussed in literature has two dimensions: nominal convergence and real convergence. The Maastricht-type criteria lays emphasis on nominal convergence (defined in terms of nominal variables interest rates, inflation, exchange rates, government deficits and debts) because they can presumably guarantee financial stability (see, Buiter, 2004) gradually leading to the real convergence of a monetary union or a quasi monetary union. The premise of this argument is anchored on the benefits of macroeconomic stability: price stability and fiscal discipline; removal of the exchange-rate risk; reduction of uncertainty concerning inflation and interest rates; increase in investment and international trade, which eventually leads to a stronger economic growth. Contrarily, real convergence which is derived from the neo-classical growth theory simply assumes convergence towards a steady state (identical to all economies). Implicitly, real convergence shows how developing countries can catch-up with the level of development of developed countries, determined by specific features of the Optimum currency Area (OAC) theory: free movement of factors of production; trade openness; diversification of production of a country; inflation and wage stability.

The relationship between real and nominal convergence has been established through the Balassa - Samuelson (BS) effect formulated concomitantly in 1964 and derived from the neo-classical economic growth theory. Summarily, the B-S effect states that, relatively faster productivity growth in the tradeables sector of catching-up accession countries will reduce wage differentials across all sectors leading to unavoidably higher inflation rate for non-tradeables with an appreciation in the real exchange rate. This implies that as economic standards increase, price levels tend rise as well (due to inflation differential, as well as rising exchange rate). These processes gradually eliminate the cost-based competitiveness of local companies. However, inflation constitutes one of the Maastricht-type criteria and an over pronounced B-S effect would impede the realization of the nominal convergence leading to the postponement of the intended monetary union.

The OCA theory (real convergence) does not emphasize on the relevance of the nominal convergence criteria in setting up a monetary union. Proponents of the OCA theory have rather focused on micro conditions that guide the formation of a monetary union than the macro criteria.

Conceivably, the arguments advanced in the OAC theory that favour the micro conditions may be justified because the transition to a monetary union initially, did not require member countries to meet any specific convergence criteria. For instance, the Dollar zone which is the largest and most stable monetary union is not premised on any convergence criteria, but rather on a political consent by member states. According to Jennings and Chomsisengphet (2000) the United States is considered an OCA because there is a high volume of commerce among the fifty states using a common currency. Other known examples - Latin Monetary Union, Scandinavian Monetary Union Norway and German Monetary Union that existed between the $18^{\text {th }}$ and early $19^{\text {th }}$ centuries adopted a monetary system based on metallic (silver and gold) standards. Similarly, the East African Common Services Organization (EACSO) and the Rand Monetary Area (RMA) are premised on some criteria inherent in the OCA theory. Likewise, the formation of the Franc zone was patently political in origin, and was eventually formed as an instrument of France's policy of economic autarky (Körner, 2010).

Similar arguments reveal that the convergence criteria may not necessarily gauge the preparedness of countries contemplating for a monetary union, since no single country has ever met all the criteria prior to the formation of a monetary union. For instance, substantial evidence have shown that most European countries in the Euro zone failed to meet the Maastricht criteria emphasized by the European Union. Reinforcing this conjecture with empirical evidence, (Haug, MacKinnon, \& Michelis, 2000) attest that not all the 12 original countries in the European Union (EU) met all the Maastricht convergence criteria before ascending into the Euro zone.

Secondly, the convergence criteria may not be sufficient enough, hence portents high cost of forfeiting monetary autonomy. For instance, having similar inflation rates by member countries prior to the formation of a monetary union may not be sufficient as observed in literature. In De Grauwe's (1996) submission, prior convergence criteria are insufficient for a monetary union because two countries for instance may have the same inflation rates and yet be structurally so different that a monetary union between them would be suboptimal.

Similar arguments show that the interest rates, debt and deficits reduction and budgetary requirements are not sufficient entry requirements for a monetary union because not all countries have the same political and economic objectives. For instance, compelling member countries to adhere to the budgetary requirement will make them lose their last macroeconomic instrument that might be used to cushion economic shocks (De Grauwe, 2003). He further submits that reducing debt and deficits prior to the entry into a union is not made because countries with high debt and deficits cannot form a monetary union, but because allowing these countries into the union will 
increase the risk of more inflation in the future and also increase the pressure for a bailout in the event of a default crisis. Again, the manifestation of the debt crises in the Euro zone gives credence to De Grauwe's assertion.

Another line of argument that contradicts the aforementioned ideas suggest that countries in a regional bloc may postulate a set of convergence criteria that will guarantee the stability of the union only if the intended monetary union was not politically motivated ab initio. Stability can be achieved only when member countries comply with the implementation process of the convergence criteria (Maruping, 2005); and when they fully commit themselves towards the process of policy harmonization (Kweka, Rweyemamu, Luvanda, Isaksen, \& Wangwe, 2007). McCarthy (2002) notes that a bad policy will ensue if the convergence criteria are met prematurely especially for countries that are exposed to asymmetric external shocks.

Hence, countries may decide to adopt and commit themselves to meeting a set of convergence criteria prior to the formation of a monetary union. The main issue is deciding how much convergence is required and how much of the convergence can follow afterwards.

\section{Demographic Indicators of ECOWAS Countries}

ECOWAS region consists broadly of two distinct zones: a Sahelian zone, largely landlocked, occupied by Mali and Burfina Faso and a more humid, forested coastal zone occupied by the remaining 13 countries of ECOWAS. Specifically, West African countries vary significantly in terms of population and geographical size. Nigeria is the largest country followed by Ghana and Cote D'Ivore, while Cape Verde and Gambia are the smallest in terms of population size. The latest values of HDI shows that Cape Verde, Ghana and Nigeria rank $123^{\text {th }}, 138^{\text {th }}$ and $152^{\text {nd }}$ among 187 countries while Guinea Bissau, Sierria Leone and Niger occupy the last positions and rank $177^{\text {th }}, 183^{\text {th }}$ and $187^{\text {th }}$. This ranking clearly indicates that ECOWAS countries have low level of human development despite the numerous natural resources that inundate the entire region.

That notwithstanding, the significant low level of HDI can be partly attributed to a number factors such high literacy rate, long years of schooling, lack of basic infrastructure, training and job opportunities etc. The average life expectancy for ECOWAS countries is 57.64 years. Cape Verde has the highest life expectancy of 78.87 years, followed by Senegal and Liberia with 63 and 60 years respectively, while Nigeria and Sierria Leone have the lowest life expectancy of 52.45 and 45.55 years respectively (World Bank Development Index, 2015).

Besides, its demographic specificity, ECOWAS countries are endowed with natural resources, with agriculture being its mainstay. The combine activities of these sectors account for approximately $82 \%$ of the total GDP in most ECOWAS countries (Gavua 2007). The main export products of ECOWAS countries are: petroleum, aluminum, gold cocoa, coffee and cotton. The reliance on agricultural exports makes ECOWAS countries vulnerable to the external shocks resulting from international market price fluctuations.

ECOWAS countries did not perform well in terms of economic growth and regional integration within the period of its establishment in 1975 up to the late 1980s simply because national programs were prioritized, member countries were fearful of Nigeria's dominance and also, the prevalence of political instability within that era (Bundu 1997). Chambas (2002) noted that, the overall performance of the sub-region was further weakened in $1990 \mathrm{~s}$, primarily because of a sharp decline in the terms of trade (-3.3\% in 1999), and political uncertainties in several countries, notably Côte d'Ivoire.

On a general note, ECOWAS countries have been witnessing positive growth rates since 2000. For instance, the total average annual growth rate increased from $3.63 \%$ in 2009 to $5.47 \%$ in 2010 , and also increased by $5.5 \%$ in 2012. However, the growth rates decline slightly by approximately 4.34 in 2011 and 2013 . Liberia, Ghana, Burkina Fasso, Nigeria, Sierra Leone and Niger have the highest average annual growth rates of $11.08 \%, 8.68 \%, 6.7 \%$, $5.87 \%$ and $5.02 \%$ respectively while Benin, Gambia, Senegal, Mali and Guinea Bissau have very low growth rates of $3.9 \%, 3.8 \%, 3.0 \%$, and $2.95 \%$ respectively. Cape Verde and Guinea Conakry has recorded the least average annual growth rates over the years. Resource-rich countries like Nigeria and Ghana benefited from the revival in commodity demand, while there was increased production in Ghana with new mineral production in Sierra Leone, Niger, and Liberia (World Bank Development Index, 2015).

The entire region had a total real GDP of $\$ 276.97$ billion with an annual average GDP per capita growth of 2.07\%. Nigeria contributed more than half of the total GDP ( $\$ 181.3$ billion) which guarantees it superiority and at the same time threatens the position and decisions of the weaker economies like Guinea Conakry, Gambia, Liberia, Cape Verde, Sierra Leone and Togo with real GDPs of just $\$ 0.74, \$ 0.84, \$ 1.29, \$ 1.37, \$ 2.5$, and $\$ 2.8$ billion respectively World Development Indicators (2013). 


\section{ECOWAS Convergence Criteria and Stability of the Proposed Monetary Union}

ECOWAS countries have expressed their desire to establish a monetary union by the year 2020 based on six macroeconomic convergence criteria. It should be noted that these criteria were initially 10 in number. The primary criteria are as follows: single digit inflation rate $\leq 5 \%$; fiscal deficit including grants/GDP ratio $\leq 3 \%$ and Gross reserves $\geq 6$ months of import cover. The secondary criteria are: the public debt to GDP ratio $\leq 70 \%$; Central Bank financing of budget deficit $\leq 10 \%$ of previous year's tax revenue; and nominal exchange rate variation should be within $+/-10 \%$. It is assumed that meeting these criteria prior to the creation of the intended monetary union may guarantee the future stability of the union.

\subsection{Annual Percentage Inflation Rate $\leq 5 \%$}

Data from World Economic Outlook (2016) shows that almost all WAEMU countries except Guinea maintained a single digit inflation rate, implying that they kept strictly to the BCEAO marginal lending rate benchmark of $4 \%$. Benin, Burkina Faso, Cote D'Ivoire, Guinea Bissau, Mali, Niger, Senegal and Togo recorded annual average inflation rates of $2.31 \%, 2.01 \%, 2.32 \%, 2.55 \%, 2.52 \%, 2.02 \%, 1.69 \%$ and $2.69 \%$ respectively below the targeted 5\% inflation rate from 2007 to 2016. Interestingly, Guinea Conakry's average annual inflation rate exceedingly went above two digits (13.56\%) due to a series of serious political unrests which constrained economic activities. All WAMZ countries exceeded the targeted inflation rate of $5 \%$ with some recording double digit rates. For instance, Ghana, Nigeria and Sierra Leon recorded an average annual inflation rate of $12.18 \%, 10.22 \%$ and $12.23 \%$, while Liberia moved closer to a two digit rate of $9.23 \%$ and Gambia just missed the targeted rate with an additional $0.5 \%$ rate. This suggests that WAEMU countries are relatively stable and qualify for a broader currency union than WAMZ countries in terms of inflation rate. The scenario in WAEMU supports the theory of the Optimum Currency Area (OCA) that price stability is guaranteed in a currency union. Consequently, a monetary union that includes both WAEMU and WAMZ countries will be unsustainable since relatively higher inflation rates in WAMZ countries may make it difficult for the envisaged currency union to maintain a fixed exchange rate over an extended period.

\subsection{Budget Deficits including Grants $\leq 5 \%$}

The entry requirement for ECOWAS countries into a monetary union is that the budget deficit including grants of each country should not exceed 5\% of its GDP by 2020. From the general outlook, WAMUE countries kept low deficits over the years from 2010 to 2015 as revealed by Global Finance Statistics (2016). That notwithstanding, only Cape Verde, Ghana and Liberia had high deficits well above 5\%, while the rest of the ECOWAS countries, had favourable ratios around the targeted value. Interestingly, Cape Verde, Guinea Bissau, and Senegal recorded surpluses in the year 2010, of $10.7 \%, 1.4 \%$ and $5.2 \%$ while Nigeria recorded a budget surplus of $0.5 \%$ in 2011 . Thus, WAMZ countries can meet the required target by 2020 if member countries are able to generate and manage their revenues properly.

\subsection{Public Debts to GDP Ratio $\leq 70 \%$}

It is required that member countries' public debt should not exceed 70\% of their GDP. Global Finance Statistics (2016) shows that only Cape Verde and Gambia debt to GDP ratios of $94.65 \%$ and $76.9 \%$ exceeded the $70 \%$ targeted value. On an average, all other countries managed to reduce their debt levels below the targeted value with the strongest economy in the region (Nigeria) consistently maintaining low levels of debt to GDP ratio relative to all ECOWAS countries. Cote D' Ivoire, Ghana, Guinea and Guinea Bissaua recorded a debt to GDP ratio of $54.46 \%$ on an average close to $70 \%$. The statistics however reveal that ECOWAS countries are committed to reducing the level of their debts, because even countries with high debts ratios are not far from the targeted value. This implies that the Euro debt crises may not replicate itself in ECOWAS if all members are really committed to meet the debt requirement prior to the creation of the monetary union. Based on this requirement, they may be considered as good candidates for a currency union.

\subsection{Gross Reserves $\geq 6$ Months of Import Cover}

West African Monetary Agency Statistics (2016) shows that all countries except for Nigeria were unable to accumulate enough foreign reserves that could cover their required six months minimum of their imports for the last three years from 2012 to 2014. Nigeria on an average recorded 8\%, while Burkina Faso, Cote d' Iviore and Mali on average recorded 3.46\%. Ghana, Gambia and Liberia recorded very low percentages of $1.2 \%, 2.8 \%$ and $1.7 \%$ respectively.

It should be noted that Guinea, Ghana and Liberia have never met this requirement implying the level of foreign reserves in these countries can not cover the recommended six months of imports. The general outlook for Nigeria is good because it has consistently kept its foreign reserves above the targeted value. However, it has not been able 
to sustain the quantum of its reserves for the past three years. The decline in Nigeria's foreign reserves may partly be attributed to exchange fluctuations and the fall in world oil prices.

The reserve entry requirement may likely disqualify almost all ECOWAS members prior to the formation of the monetary union since market forces still remain uncertain and external shocks keep re-orientating the economic activities of these countries. Therefore, the need for ECOWAS countries to diversify their economies is imperative.

\subsection{Central Bank Financing of Budget Deficit $\leq 10 \%$}

The limit to which Central Banks can finance governments' deficits is reported in West African Monetary Agency Statistics (2016). The data reveals that all countries consistently kept their deficit financing below the required targeted $10 \%$. It is observed that Ghana, Guinea and Sierra Leon almost reached the targeted value for some years, while, Nigeria, Cape Verde and Liberia adopted a "zero-financing culture" consistently maintaining a zero deficit financing over the years. Though all the ECOWAS counties have complied to this convergence criterion, other countries that occasionally use their national Central Banks to finance their deficits will find it costly to relinquish their monetary sovereignty.

\subsection{Exchange Rate Stability $+/-10 \%$}

Exchange rate variations between ECOWAS countries must not be more or less than $10 \%$ prior to the formation of the monetary union. The West African Monetary Agency Statistics (2016) shows that all ECOWAS countries have kept their exchange rate variations with each member within the required minimum and maximum targets between 2006 and 2014. The Cedi, Naira and Leone showed smaller margins of fluctuations, while the Dalasi, Guinean and Senegal Franc and Liberian Dollar recorded higher margins of fluctuations in their exchange rates. Interestingly, Ghana and the Gambia have consistently depreciated their exchange rate since 2009, while the Escudo depreciated only twice. Keeping within the band limits shows that ECOWAS countries have made efforts to stabilize the exchange rate which indicates that trade activities among ECOWAS countries to a greater extent is free.

\section{Conclusion}

ECOWAS countries have expressed their desire to establish a monetary union by the year 2020 based on six macroeconomic convergence criteria. The desire is predicated on a series of strategies and various treaties ratified and signed by various ECOWAS Heads of governments and Central Banks' Governors with more emphasis laid on a set of convergence criteria that must be satisfied by all member countries before they ascend to the envisaged monetary union. Therefore, the objective of this study is to ascertain whether ECOWAS countries have met all the macroeconomic convergence criteria making them fit for a monetary union. The analyses indicate that no ECOWAS country has met all the convergence criteria at any given point in time implying that the level of macroeconomic convergence in the region still remains inadequate relative to the set targets. However, WAEMU sub-set economies have met three of the criteria -public debts to GDP Ratio, deficits including grants, annual percentage inflation rate. The simple reason is that WAEMU is already an existing monetary union with a common stabilization policy.

In order not to compromise the stability of the envisaged monetary union, the governments of West African States should further, shift the targeted date for the monetary union beyond 2020 since this will give ample time for member countries to work fervently towards fulfilling the optimum currency area criteria. To ensure that these targets are met, the existing institutions responsible for macroeconomic surveillance and the enforcement of fiscal discipline should be reinforced. This will enable them to easily analyse claims on the statues of macroeconomic variables for the various countries and provide substantial evidence that member countries have fully satisfied the nominal as well as the real convergence criteria.

Before adopting a common currency for the entire West Africa, English speaking countries that constitute WAMZ, should first of all be compelled to form a second monetary union in the region. This will make them to fully understand the dynamics of a common stabilization policy and how it can influence the attainment of the macroeconomic convergence criteria without any compromise.

\section{References}

Balassa, B. (1964). The Purchasing-Power Parity Doctrine: A Reappraisal. Journal of Political Economy, 72(6), 584-596. https://doi.org/10.1086/258965

Buigut, S. (2006). Monetary Policy Transmission Mechanism: Implications for the Proposed East African Community (EAC) Monetary Union. [Online]. Working Paper. Retrieved June 20, 2014, from http://www.csae.ox.ac.uk/.../300-Buigit.pdf 
Buigut, S. (2011). A Fast-Track East African Community Monetary Union? Convergence Evidence from a Cointegration Analysis. International Journal of Economics and Finance, 3(1), 255-261. https://doi.org/10.5539/ijef.v3n1p255

Buigut, S., \& Valev, N. (2005). Is the Proposed East African Monetary Union an Optimal Currency Area? A Structural Vector Autoregression Analysis. World Development, 33(12), 260-267. https://doi.org/10.1016/j.worlddev.2005.06.006

Bundu, A. (1997). ECOWAS and the Future of Regional Integration in West Africa. Regional Integration and Cooperation in West Africa: A Multidimensional Perspective, Ed. Real, Lavergne, Eritrea: Africa. World Press Chapter, 1, 1-47.

Business News Staff (2014). ECOWAS Relaxes Compliance Criteria to Hasten Monetary Union by 2020. Retrieved from http://www.thisdaylive.com/articles/ecowas-relaxes-compliance-criteria-to-hastenmonetary-union-by-2020/183669/

Chambas, M. (2002) Fostering Regional Integration through NEPAD Implementation. Annual Report of the Executive Secretary of ECOWAS. Abuja.

De Grauwe, P. (1996). International Money, Post-war Trends and Theories. Oxford University Press, Second Edition, March.

De Grauwe, P. (2003). Economics of Monetary Union (5e). Oxford: Oxford University Press: Oxford, UK.

Essien, A. E. (2009). Introducing a Common Currency: The ECOWAS Experience. Paper Presented at the ECOWAS - EI Academy in Comparative Regional Integration, Centre for European Integration Studies, Bonn, Germany, March 16-28

Gavua, I. (2007). Economic Community of West African States Regional integration Process: A Study of the New Regionalism Phenomenon in Africa .Unpublished M.Sc Thesis, Department of Management and Engineering Linkopings University, Sweden.

Haug, A., MacKinnon, J., \& Michelis, L. (2000). European Monetary Union: A cointegration analysis. Journal of International Money and Finance, 19(3), 419-432. https://doi.org/10.1016/S0261-5606(00)00013-9

Jennings, T., \& Chomsisengphet, S. (2000). NAFTA: An optimum currency area? International Economic Review, $1-5$

Körner, H. (2010). The Franc Zone of West and Central Africa. A Satellite System of European Monetary Union. Retrieved from http://archive.intereconomics.eu/downloads/getfile.php?id $=226$

Kweka, J., Rweyemamu, D., Luvanda, E., Isaksen, J., \& Wangwe, S. (2007). Macro-Economic Convergence Policy in the Southern African Development Community: Prospects and Challenges. In Jonathan Mayuyuka Kaunda (Ed.): Proceedings of the 2006 FOPRISA Annual Conference. Gaborone: Botswana Institute for Development Policy Analysis, pp. 235-272

Maruping, M. (2005). Challenges for Regional Integration in Sub-Saharan Africa. Retrieved from http://www.fondad.org/uploaded/Africa\% $\% 2520$

Mccarthy, C. (2002). Macroeconomic Convergence in SADC: A Policy Perspective for the Central Banks of the Integration Arrangement. Policy Paper. Retrieved from http://www.sarpn.org/documents/d0000559/P512Macro-economic-SADC.pdf

Onuba, I. (2015). Single Currency: Convergence Criteria, Barrier to Economic Integration in W/Afr-BusinessNairaland.

Retrieved

from

http://news.punchng.com/index.php?option=com_k2\&view=item\&id=1573\%3Asingle-currency-

convergence-criteria-barrier-to-economic-integration-in-west-africa\&Itemid=543

Samuelson, P. (1964). Theoretical Notes on Trade Problems. The Review of Economics and Statistics, 46(2), 145154. https://doi.org/10.2307/1928178

WAMI. (2002). Questions and answers on the West African Monetary Zone. Retrieved from http://www.ecowas.int/specialized-agencies/west-african-monetary-institute-wami/

WorldBank. (20015). World Development Indicators: Statistic Department, Publications Services: Washington, DC 20433 USA.

\section{Copyrights}


Copyright for this article is retained by the author(s), with first publication rights granted to the journal.

This is an open-access article distributed under the terms and conditions of the Creative Commons Attribution license (http://creativecommons.org/licenses/by/4.0/). 